\title{
Beware the patient with a headache in the accident and emergency department
}

\author{
D. I. FODDEN, R. C. PEATFIELD* \& P. L. MILSOM
}

Departments of Accident and Emergency Medicine and *Neurology, St fames's University Hospital, Leeds, England

\section{SUMMARY}

We have reviewed the 130 patients presenting to an accident and emergency (A \& E) department with a headache, followed up for 2 years. These are infrequent attenders but we have found that there is a high incidence of serious neurological pathology $(16 \%)$ in this group of patients. We suggest that patients presenting to the A \& E department with headache should be thoroughly examined and investigated and in the absence of a definite benign diagnosis should at least be admitted for a period of observation.

\section{INTRODUCTION}

Patients presenting to emergency rooms and other primary health care centres with a headache account for between $1.3 \%$ and $2.5 \%$ of all attendances (Dickman \& Masten, 1979; Dhopesh et al., 1979; Leicht, 1980; Becker et al., 1987). When presenting to A \& E departments, these patients are often looked upon as inappropriate attenders and may not get the attention they deserve. In other published series of patients with headaches from general practice, neurology or headache clinics and A \& E departments, the incidence of structural pathology is very low, ranging between $0.3 \%$ and $5 \%$ (Dhopesh et al., 1979; Jerrett, 1979; Olesen et al., 1979; Leicht, 1980; Joseph et al., 1985; Bass et al., 1986; Peatfield, 1986; Perkin, 1986). Our experience has suggested that patients presenting to the $\mathrm{A} \& \mathrm{E}$ department with a headache had a much higher incidence of serious pathology. This study was conducted in order to determine the number of patients presenting with this symptom and the prevalence of serious neurological pathology in this group.

Correspondence: Mr D. I. Fodden, Registrar in Accident and Emergency Medicine, St fames's University Hospital, Leeds LS9 7TF, England. 


\section{METHODS}

We carried out a retrospective analysis of the 35709 patients who presented to the A \& E Department at St James's University Hospital, Leeds, over a consecutive 6month period from 1 January 1985, followed up for 2 years. The patient record ledger was examined and details were taken from the records of those patients who had presented complaining primarily of headache. A note was also made of whether the patient was referred by the general practitioner or self-referred. If a patient was admitted, the hospital records were examined in order to determine the final diagnosis. The general practitioners of patients who were discharged from the department were contacted to see if our diagnosis had needed modification or if any other significant pathology had arisen since initial presentation.

\section{RESULTS}

We found 130 patients who presented to the department with a headache. This was $0.36 \%$ of all new patients, a considerably lower proportion than in other published series.

It was not possible to secure full follow-up notes of 24 patients because they had moved out of the area and the new general practitioner could not be traced or the notes could not be traced. We therefore have full records for 106 patients of which $40(38 \%)$ were referred by their own general practitioner and $38(36 \%)$ were male. The average age was 35.8 years, Table I shows the age/sex distribution and Table 2 shows the final diagnoses. The 24 patients for whom we have no follow-up data only differed from our study group in that $13(54 \%)$ were male (Table 3 ).

The largest group of patients had non-specific headache $(26 \%)$ whilst migraine, including cluster headaches, accounted for $19 \%$, and $16 \%$ were related to general medical problems. A further $13 \%$ were thought to have a tension or psychogenic headache and $10 \%$ were related to generalized febrile illnesses.

Table 1 Age/sex details of our patients

\begin{tabular}{crrr}
\hline $\begin{array}{c}\text { Age } \\
\text { (years) }\end{array}$ & $M$ & F & Total \\
\hline $0-10$ & 2 & 0 & 2 \\
$11-20$ & 9 & 11 & 20 \\
$21-30$ & 8 & 25 & 33 \\
$31-40$ & 8 & 9 & 17 \\
$41-50$ & 5 & 6 & 11 \\
$51-60$ & 2 & 6 & 8 \\
$61-70$ & 1 & 4 & 5 \\
$71-80$ & 3 & 5 & 8 \\
$81-90$ & 0 & 2 & 2 \\
Total & 38 & 68 & 106 \\
\hline
\end{tabular}


Table 2 Details of final diagnoses

\begin{tabular}{|c|c|c|c|}
\hline & & & Number \\
\hline Non-specific & & & 28 \\
\hline Migraine/cluster & (20) & $\begin{array}{l}\text { Migraine } \\
\text { Cluster }\end{array}$ & $\begin{array}{r}19 \\
1\end{array}$ \\
\hline General medical & (17) & $\begin{array}{l}\text { Hypertension } \\
\text { Referred from cervical spine } \\
\text { Scleritis } \\
\text { Dental } \\
\text { Eye strain } \\
\text { Sinusitis } \\
\text { Temporal arteritis } \\
\text { Urinary tract infection } \\
\text { Hyperthyroidism } \\
\text { Alcohol ingestion }\end{array}$ & $\begin{array}{l}4 \\
3 \\
2 \\
2 \\
1 \\
1 \\
1 \\
1 \\
1 \\
1 \\
1\end{array}$ \\
\hline Psychogenic & & & 14 \\
\hline Febrile illness & (10) & $\begin{array}{l}\text { Viraemia } \\
\text { Chickenpox } \\
\text { Tonsillitis } \\
\text { Influenza } \\
\text { Mumps }\end{array}$ & $\begin{array}{l}3 \\
2 \\
2 \\
2 \\
1\end{array}$ \\
\hline Intracranial bleed & (9) & $\begin{array}{l}\text { Subarachnoid } \\
\text { Intracerebral } \\
\text { Subdural }\end{array}$ & $\begin{array}{l}5 \\
3 \\
1\end{array}$ \\
\hline $\begin{array}{l}\text { Raised intracranial } \\
\text { pressure }\end{array}$ & (6) & $\begin{array}{l}\text { Glioma } \\
\text { Angioma } \\
\text { Benign intracranial hypertension }\end{array}$ & $\begin{array}{l}3 \\
2 \\
1\end{array}$ \\
\hline Meningitis & & & 2 \\
\hline & & Total & 106 \\
\hline
\end{tabular}

Seventeen patients, all of whom were aged over 16 years, had serious neurological pathology, including intracranial haemorrhage (mean age 55.1 years), raised intracranial pressure (mean age 40.0 years) and meningitis (mean age 32.5 years). Of these 17 patients, three had no abnormal physical signs but were admitted on the strength of the history alone and a total of nine had been referred by their general practitioner and eight self-referred.

The departmental diagnosis required modification after in-patient investigation or was disputed by the general practitioner in $20 \%$ but no patient in this series, who was ultimately found to have had a serious condition, was discharged from the department (Tables $4 \& 5$ ). 
Table 3 Provisional diagnoses of those patients for whom full follow up data was not available

\begin{tabular}{|c|c|c|c|}
\hline Age & Sex & $\begin{array}{l}\text { Provisional } \\
\text { diagnosis }\end{array}$ & \\
\hline Unknown & $\mathrm{F}$ & Inebriate & \\
\hline 11 & $M$ & Epilepsy & \\
\hline 14 & $\mathbf{F}$ & Migraine & \\
\hline 17 & $\mathbf{F}$ & Nil & \\
\hline 21 & $\mathbf{F}$ & Migraine & \\
\hline 22 & $\mathbf{F}$ & Nil & \\
\hline 22 & $M$ & Nil & \\
\hline 22 & $M$ & Nil & \\
\hline 23 & $\mathbf{F}$ & Tension & \\
\hline 24 & $\mathbf{M}$ & Migraine & \\
\hline 29 & $M$ & Nil & \\
\hline 31 & $\mathbf{M}$ & Nil & \\
\hline 33 & $M$ & Nil & \\
\hline 33 & $\mathbf{M}$ & Migraine & \\
\hline 34 & $\mathbf{M}$ & Nil & \\
\hline 36 & $\mathbf{F}$ & Space occupying lesion & \\
\hline 41 & $\mathbf{F}$ & Migraine & \\
\hline 49 & $\mathbf{F}$ & Hypertension & \\
\hline 50 & $\mathbf{F}$ & Migraine & \\
\hline 52 & $\mathbf{M}$ & Thrombophlebitis & \\
\hline 62 & $\mathbf{M}$ & Migraine & ก \\
\hline 69 & $\mathbf{M}$ & Cerebrovascular incident & 음 \\
\hline 72 & $\mathbf{M}$ & Nil & $\lesseqgtr$ \\
\hline 71 & $\mathbf{F}$ & Psychogenic & $\frac{\mathrm{O}}{2}$ \\
\hline
\end{tabular}

\section{DISCUSSION}

Headache is a common symptom and accounts for between $1.3 \%$ and $2.5 \%$ of all primary health care consultations (Dhopesh et al., 1979; Dickman \& Masten, 1979; Leicht, 1980; Becker et al., 1987). The frequency of serious neurological pathology in patients with headache is generally thought to be very low. Our experience suggests that

Table 4 Details of those patients who were admitted and the diagnoses required modification

\begin{tabular}{|c|c|c|c|}
\hline Age & Sex & $\begin{array}{l}\text { Provisional } \\
\text { diagnosis }\end{array}$ & $\begin{array}{l}\text { Final } \\
\text { diagnosis }\end{array}$ \\
\hline 18 & $\mathbf{M}$ & Subarachnoid haemorrhage & Non-specific \\
\hline 23 & $\mathbf{M}$ & Migraine & Nil further \\
\hline 27 & $\mathbf{F}$ & Hypertension & Migraine \\
\hline 44 & $\mathbf{M}$ & Viraemia & Hypertension \\
\hline 59 & $\mathbf{F}$ & Space occupying lesion & Non-specific \\
\hline 66 & $\mathbf{F}$ & Migraine & Non-specific \\
\hline 73 & $\mathbf{M}$ & Pneumonia & Urinary tract infection \\
\hline
\end{tabular}


Table 5 Details of those patients who were not admitted and the diagnoses required modification

\begin{tabular}{llll}
\hline Age & Sex & $\begin{array}{l}\text { Provisional } \\
\text { diagnosis }\end{array}$ & $\begin{array}{l}\text { Final } \\
\text { diagnosis }\end{array}$ \\
\hline 10 & M & Viraemia & Nil further \\
13 & F & Migraine & Nil further \\
16 & M & Migraine & Mumps \\
19 & F & Inhalation of paint fumes & Migraine \\
22 & F & Migraine & Hypertension \\
22 & M & Migraine & Sinusitis \\
22 & F & Viraemia & Hyperthyroidism \\
23 & F & Tension & Viraemia \\
24 & F & Migraine & Nil further \\
27 & F & Sinusitis & Nil further \\
28 & F & Psychogenic & Nil further \\
29 & F & Migraine & Dental \\
29 & F & Tension & Eye strain \\
30 & F & Hypertension & Non-specific \\
30 & F & Migraine & Non-specific \\
40 & F & Migraine & Psychogenic \\
42 & F & Migraine & Hypertension \\
42 & M & Tension & Migraine \\
48 & F & Tendinitis & Nil further \\
51 & F & Tension & Cervical spondylosis \\
72 & F & Neuralgia & Nil further \\
\hline
\end{tabular}

many doctors feel that it is an inappropriate use of an $\mathrm{A} \& \mathrm{E}$ department for patients to attend with a headache. Although headaches are extremely common, it is very unusual for patients to present to an $\mathrm{A} \& \mathrm{E}$ department with this symptom: in our study there were only 130 patients out of a total of 35709 in the 6 months of the study, overall $0.36 \%$ of all departmental attendances.

Despite the low attendance rate there does appear to be a high incidence of serious neurological pathology in this group of patients. We suggest that the patients attended the A \& E department because they felt that their headache was unusual, for example more severe or longer-lasting than previously experienced. A further group attended for immediate investigation having been referred by their general practitioner on the basis of the history or physical findings.

We feel, therefore, that all such patients are treated with a great deal of respect and that all new doctors in an A \& E department should be warned not to treat these patients as inappropriate attenders. We would further suggest that if a patient attends the $\mathrm{A} \& \mathrm{E}$ department with a headache and a definite benign diagnosis cannot be reached, the history is suggestive of serious neurological pathology or the patient exhibits abnormal neurological physical signs then he deserves admission for a period of observation and possibly further investigation. This is not likely to become a burden on the hospital because the number of these patients is relatively small. 


\section{ACKNOWLEDGEMENTS}

We are grateful to Dr I. D. Adams and Dr R. N. Illingworth who gave us access to the patient records and also gave advice throughout the study.

\section{REFERENCES}

Bass M. J., McWhinney I. R., Dempsey J. B. et al. (1986) Predictors of outcome in headache patientsలँ presenting to family physicians-a one year prospective study. Headache 26, 285-94.

Becker L. A., Iverson D. C., Reed F. M., Calonge N., Miller R. S. \& Freeman W. L. (1987) A study of headache in North American primary care. Journal of the Royal College of General Practitioners 37, 400-3. $\vec{\omega}$

Dhopesh V., Anwar R. \& Herring C. (1979) A retrospective assessment of emergency department patients with complaint of headache. Headache 19, 37-42.

Dickman R. L. \& Masten T. (1979) The management of non-traumatic headache in a university hospitalö emergency room. Headache 19, 391-6.

Jerrett W. A. (1979) Headaches in general practice. The Practitioner 222, 549-55.

Joseph R., Cook J. E., Steiner T. J. \& Rose F. C. (1985) Intracranial space-occupying lesions in patients $\bigcirc$ attending a migraine clinic. The Practitioner 229, 477-81.

Leicht M. J. (1980) Non-traumatic headache in the emergency department. Annals of Emergency Medicine 9 , 404-9.

Olesen J., Aebelholt A., Veilis B. (1979) The Copenhagen acute headache clinic: organization, patient material and treatment results. Headache 19, 223-7.

Peatfield R. C. (1986) Headache. Berlin, Springer Verlag.

Perkin G. D. (1986) Basic Neurology. Chichester, Horwood. 